\title{
50 ANOS DA PEDAGOGIA DO OPRIMIDO: REFLEXÕES SOBRE (RE)EXISTÊNCIA NO BRASIL E NA AMÉRICA LATINA
}

\author{
Valéria Oliveira de Vasconcelos ${ }^{\mathrm{i}}$ \\ Carlos Rodrigues Brandão ${ }^{\text {ii }}$
}

\begin{abstract}
Resumo: No presente artigo nos propomos a levantar reflexões sobre como a Pedagogia do Oprimido contribui para seguirmos pensando nossa existência. Problematizando sobre nossas vidas sociais organizamos o texto em oito partes: após notas iniciais e breve apresentação traçamos algumas ponderações sobre qual a "cara" de nosso povo e de nosso país; em seguida traçamos considerações sobre o contexto atual e a contemporaneidade das proposições de Freire; na quinta parte nos perguntamos sobre temores e elementos que vêm conformando, na luta e na resistência, nossa identidade; na sexta parte trazemos à tona algumas costuras entre a educação bancária e a falácia de um projeto de escola amordaçada. Tradição, família e propriedade são tematizadas na sétima parte para, finalmente, apontarmos anúncios possíveis.
\end{abstract}

Palavras chave: Pedagogia do Oprimido. Resistência. Denúncias. Anúncios.

\section{AÑOS DE LA PEDAGOGÍA DEL OPRIMIDO: REFLEXIONES SOBRE (RE) EXISTENCIA EN BRASIL Y EN AMÉRICA LATINA}

Resumen: En el presente artículo nos proponemos levantar reflexiones sobre cómo la Pedagogía del Oprimido contribuye para que sigamos pensando nuestra existencia. Problematizando sobre nuestras vidas sociales organizamos el texto en ocho partes: tras notas iniciales y breve presentación trazamos algunas ponderaciones sobre cuál la cara de nuestro pueblo y de nuestro país; en seguida tesemos algunas consideraciones sobre el contexto actual y la contemporaneidad de las proposiciones de Freire; en la quinta parte nos preguntamos sobre temores y elementos que vienen conformando, en la lucha y en la resistencia, nuestra identidad; en la sexta traemos a la luz costuras entre la educación bancaria y la falacia de un proyecto de escuela amordazada. Tradición, familia y propiedad son tematizadas en la séptima parte para, finalmente, apuntar anuncios posibles.

Palabras llave: Pedagogía del Oprimido. Resistencia. Denuncias. Anuncios.

\section{Notas iniciais}

Nos últimos anos da presente década lembramos as datas de vários acontecimentos cujas lições e repercussões estão de algum modo presentes entre nós até hoje.

Assim, em 1960, Paulo Freire alia-se a uma sua primeira equipe fora do SESI, onde trabalharam durante nove anos, e onde provavelmente terá adquirido conhecimentos sobre dinâmica de grupos que iriam desaguar na ideia de "círculos de cultura". Ao lado de Aurenice 
Cardoso, Jomard Muniz de Brito e Jarbas Maciel, através do Serviço de Extensão Comunitária SER, da então Universidade do Recife, ele inicia ações de alfabetização de adultos em Pernambuco e no Rio Grande do Norte (e a experiência de Angicos).

É junto com pessoas desta primeira equipe de educadores que ele elabora os termos iniciais de não apenas um "método de alfabetização de adultos" que o tornaria conhecido, mas todo um "Sistema Paulo Freire de Educação". Este "sistema de educação" previa ações que iam da alfabetização de crianças e também de jovens e adultos até uma "universidade popular". Quatro artigos desta “equipe pioneira” foram publicados em 1964 na Revista da Universidade do Recife e podem ser hoje encontrados no livro coordenado por Osmar Fávero: Cultura popular e educação popular - memoria dos anos sessenta ${ }^{\text {iii }}$.

Em 2012 lembramos os cinquenta anos da realização no Recife do $1^{\circ}$ Encontro Nacional de Movimentos de Cultura Popular. Em boa medida, uma iniciativa de Paulo Freire e seus companheiros e companheiras, em tempos em que expressão "educação popular" era inexistente ou muito rara. E em que o que nos unia eram as frentes de criação, diálogo e luta dos “movimentos de cultura popular". Trabalhos pioneiros de educação junto ao povo especialmente os de alfabetização - constituíam uma das áreas de ação da "cultura popular".

Nos anos finais de 1963 Paulo Freire e sua equipe ampliada são convidados pelo então Ministro da Educação, Paulo de Tarso, a estenderem a todo o Brasil a "experiência de Angicos" através de uma Campanha (ou Cruzada) Nacional de Alfabetização. Logo os preparativos para um trabalho de tal dimensão foram iniciados ${ }^{\mathrm{iv}}$. Antes de a grande Cruzada ser iniciada, em abril de 1964, é desfechado o golpe militar que impôs uma ditadura durante 21 anos no País. Paulo Freire é preso, interrogado e exilado. Junto com a esposa e os quatro filhos, outros amigos, como Thiago de Mello, Ernani Maria Fiori, Francisco Wefford e Augusto Boal (que terá antes criado o Teatro do Oprimido) Paulo Freire parte para o Chile.

Durante sua estada no Chile ele se dedica a apoiar projetos rurais, através sobretudo de uma cooperativa de camponeses, o INDAP ${ }^{\mathrm{v}}$.

Durante os anos no Chile torna-se amigo de Jacques Chonchol, então ministro da agricultura e de sua esposa, a brasileira Maria Edy. Em seu tempo de permanência no Chile redige à mão, em folhas soltas de papel, o Pedagogia do Oprimido. Antes de viajar rumo à Bolívia, aos EUA e, depois, para longos anos na Europa (com várias incursões à África sobretudo as ex-colônias libertadas de Portugal) leva com ele, embrulhado em papel, o manuscrito do livro. Ele se acompanha de uma carta cuja parte final merece ser transcrita aqui. 
... Deixava o Brasil. Trazia o Brasil. Chegava sofrendo a ruptura entre o meu projeto e o projeto do meu País.

Encontrei vocês. Acreditei em vocês. Comprometi-me com o seu compromisso no INDAP que você partejava.

Queria que vocês recebessem estes manuscritos de um livro que pode não prestar, mas que encarna a profunda crença que tenho nos homens, com uma simples homenagem a quem muito admiro e estimo.

Paulo,

Santiago,

Primavera de 68.

\title{
2. Apresentação
}

\begin{abstract}
Nossa autêntica identidade coletiva nasce do passado e se nutre dele - pegadas sobre as quais caminham nossos pés, passos que representem nossas andanças de agora - mas não cristaliza na nostalgia. Somos o que fazemos, e, sobretudo o que fazemos para mudar o que somos: nossa identidade reside na ação e na luta. Por isso a revelação do que somos implica na denúncia do que nos impede de ser o que podemos ser (GALEANO, Eduardo) ${ }^{\text {vi }}$.
\end{abstract}

Afirma Ernani Maria Fiori, nas primeiras linhas do prefácio à Pedagogia do Oprimido, que Paulo Freire é um pensador comprometido com a vida: não pensa ideias, pensa a existência. Desde essa prerrogativa aceitamos o desafio de escrever o presente artigo pensando nossa existência, que ganha a intemporalidade, ao passo em que marca o tempo vivido hoje. Alertamos que o tom do presente artigo - talvez um tanto aguerrido e militante - em boa medida reflete o que o próprio Freire disse e escreveu ao longo de sua vida. Inclusive em sua Pedagogia do Oprimido.

Vivemos um período de retrocesso, de novos e mais perversos desmandos daqueles que nos oprimem cotidianamente, e ainda se travestem de "bom mocismo": os terratenientes - do gado, da soja, da madeira, do minério, da água, das cidades - luzindo suas ferozes e gigantescas caminhonetes, morando nas alturas de prédios "dubaianos" (termo que a-diverte) cujo modus vivendi ilude, seduz e se traduz em "sonho de consumo".

Estamos sendo acossados por muitos que, em nome de suas ganâncias, manipulam, corrompem, compram, vendem, matam, violentam... Em nome de deus. Do deus OURO, como nos ensina Dussel (1974). E arrancam nossas latino-americanas entranhas desde que pisaram os europeus nessas terras, há mais de 500 anos.

E nos perguntamos: afora eles e para além "deles", os empresários que controlam políticos e políticos que de forma servil servem a si próprios, ao servirem ao capital, ao OURO, resta o que? Resta quem?

Não apenas restamos, mas estamos e nos somamos: Nós! 
E sobre "nós" e sobre o sublime mistério do "entre-nós", que por um momento nos fale uma mulher poeta e educadora, Adélia Prado: Saberemos viver uma vida melhor que esta, quando mesmo chorando é tão bom estarmos juntos?

Escreveremos, portanto, sobre nós, “os outros". Nós, as mulheres e os homens que somos, individual e coletivamente, a substância real e a realidade suprema daquilo a que damos o nome de vida social.

Refletindo sobre nossa existência e nossas vidas sociais organizaremos, em oito despretensiosas e limitadas "unidades epocais"vii , o presente artigo.

Após notas iniciais e breve apresentação traremos algumas reflexões sobre qual a "cara" de nosso povo e de nosso país. Que "cara" cremos que temos, que "cara" nos querem conferir, que "cara" queremos. Essa temática perpassará todo o trabalho.

$\mathrm{Na}$ quarta parte traçamos algumas considerações sobre a temeridade do contexto atual de golpe de Estado e como as proposições de Freire, em 1968, desafortunadamente, cabem muito bem ainda nos dias atuais. Claro que não por seu valor transcendente, mas pela gravidade dos fatos denunciados, ontem e hoje.

Na quinta parte, tendo como substrato indagações persistentes em nós, nos perguntamos quem são aqueles a quem devemos temer e alguns dos movimentos/elementos que vêm conformando, na luta e na resistência, nossa identidade.

$\mathrm{Na}$ sexta parte trazemos à tona costuras entre a educação bancária e a falácia de um projeto de escola amordaçada.

Tradição, família e propriedade são problematizadas na sétima parte para, finalmente, levantarmos anúncios possíveis na última parte do texto.

Sigamos, pois, ao nosso diálogo...

\section{Brasil mostra a tua cara}

Iniciamos com uma provocação sobre a urgência de nosso país, de nosso povo, mostrar sua identidade. Para nós isso é uma demanda, é um apelo ou é um desafio que desde muito tempo se repete: “Brasil, mostra a tua cara!”. E esse quase sempre é um grito que sugere a nós mostrarmos como sendo a verdadeira, uma "cara" desgraçada, pobre, desqualificada, infeliz.

Seria o "complexo de vira-latas" retratado por Nelson Rodrigues? próprio se denominou de um patriotismo inatual e agressivo afiançando que: 
Eu vos digo: - o problema do escrete não é mais de futebol, nem de técnica, nem de tática. Absolutamente. É um problema de fé em si mesmo. O brasileiro precisa se convencer de que não é um vira-latas [...]. Insisto: - para o escrete, ser ou não ser viralatas, eis a questão.

E agora, acabou o Carnaval e está mais do que na hora de mostrarmos, a nós e aos outros, o verdadeiro rosto de quem somos. Chega de repetir ano após ano os estribilhos, que como num péssimo samba-enredo nos mostram - as gentes deste País - como vira-latas, como na verdade nós não o somos. Emprestando as palavras de Anibal Quijano (2005), “[...] é tempo de aprendermos a nos libertar do espelho eurocêntrico onde nossa imagem é sempre, necessariamente, distorcida. É tempo, enfim, de deixar de ser o que não somos”.

E acreditamos que há poucos intelectuais mais adequados que Paulo Freire e sua Pedagogia do Oprimido para auxiliar-nos nessa reflexão.

Há 50 anos o Brasil vivia os primeiros anos de uma Ditatura Militar que perdurou 21 anos, como retrata o excelente documentário de Camilo Tavares de 2013: O dia que durou 21 $\operatorname{anos}^{i x}$.

O contexto social e político em 1968 guarda indigestas semelhanças com os tempos vividos hoje no Brasil. Nas palavras do próprio Freire, em Pedagogia da Esperança (1992):

O livro [Pedagogia do oprimido] apareceu numa fase histórica cheia de intensa inquietação. Os movimentos sociais na Europa, nos Estados Unidos, na América Latina, em cada espaço-tempo com suas características próprias. A luta contra a discriminação sexual, racial, cultural, de classe, a luta em defesa do ambiente, os Verdes, na Europa. Os golpes de Estado com a nova face, na América Latina, e seus governos militares que se alongaram da década anterior. Os golpes de Estado agora ideologicamente fundados, e todos eles ligados de uma ou de outra maneira ao carro-chefe do Norte, na busca de viabilizar o que lhe parecia dever ser o destino capitalista do continente [...]. (FREIRE,1992, p.62).

Atualmente, como mais uma artimanha de um regime de poder econômico, político e cultural (sobretudo midiático) que, talvez de forma mais perversa do que entre os militares da ditadura (eles eram mais honestos), vivenciamos persistentes momentos em que, cada vez com maior amplitude, são colonizados mentes e espíritos, a começar por se apresentarem sempre "eles" como a alternativa única para um futuro viável entre o amanhã e a eternidade.

Em 1968, no prefácio da Pedagogia do Oprimido anunciava Fiori:

Em regime de dominação de consciências, em que os que mais trabalham menos podem dizer a sua palavra e em que multidões imensas nem sequer têm condições pura trabalhar, os dominadores mantêm o monopólio da palavra, com que mistificam, massificam e dominam. Nessa situação, os dominados, para dizerem a sua palavra, têm que lutar para toma-la. Aprender a tomá-la dos que a detêm e a recusam aos demais, é 
um difícil, mas imprescindível aprendizado - é a "pedagogia do oprimido" (Firoi apud FREIRE, 1968, p.15).

E não ao acaso neste Carnaval de 2018, e sob um estado de golpe político-parlamentar, duas escolas de samba do Rio de Janeiro nos deram uma aula de retrato de nós mesmos, entre nossas misérias, nossas lutas, nossas perdas e também nossas esperanças e vitórias. Cantaram nossa palavra em plena "Marquês de Sapucaí", emudecendo comentaristas e enfurecendo aqueles que "mantêm o monopólio da palavra, com que mistificam, massificam e dominam".

Para os detentores do poder, "Melhor será, que a situação concreta de injustiça não se constitua num 'percebido' claro para a consciência dos que a sofrem” (FREIRE, 1977, p. 20). E nada como a cultura para subverter a "ordem" que se impõe pelo governo golpista, como epíteto de sua empreitada: esse grupo se propõe a si mesmo como zelador da "Ordem" e do "Progresso" - Ordem como disciplina, domesticação! Progresso (econômico, e de alguns, em detrimento da maioria) como meta.

\section{Temerosos tempos}

Consideramos que o que se praticou em 2016 e perdura até agora, contra um governo eleito nas urnas, é mais uma experiência de violência política. Não foi a primeira. Poderia ser a última. Ela é a nosso ver algo pior do que um golpe. Lembramos que em toda a América Latina as forças submetidas aos interesses capitalistas sempre souberam - entre golpes militares e golpes parlamentares (como o que vivemos agora) - comprometer ou mesmo estancar avanços dos governos, das frentes e das causas populares. O sistema capitalista é histórica e intrinsecamente perverso. Ele é excludente, injusto, devastador. E aquilo a que a que damos o sonoro nome de "corrupção" é apenas uma de suas assinaturas.

Não devemos nos iludir. O governo deposto em 2016, em boa medida já era "presa" dos poderes que o derrubaram (Michel Temer era vice da chapa de Dilma!). Daí as razões substantivas pelas quais reformas estruturais da maior importância e urgência - em nome da justiça, da inclusão e da felicidade de praticamente todas as pessoas desta nação brasileira permanecerem paralisadas entre arquivos, gavetas e corredores de palácios e congressos.

O governo que se apossou do poder no mesmo ano não é "presa" dos iguais poderes do "mundo dos negócios", antagônico ao "mundo da vida" que defendemos. Ele é um seu aliado, um seu emissário, um seu servidor. E as apressadas primeiras medidas tomadas, tanto no campo da exploração do petróleo quanto no do controle da educação, vem sendo um eloquente testemunho do rumo desse (des)governo usurpador. 
Apropriaram-se, ademais, de nossa bandeira nacional como "símbolo augusto" de sua ideologia, unicamente para si e os seus, reinaugurando um sectarismo mordaz, dividido em cores (verde-amarelo X vermelho) e em sabores (coxinhas X mortadelas/petralhas).

Para Freire "não há como surpreender os eventos históricos isolados, soltos, desconectados, coisificados, parados, mas em relação dialética com outros, seus opostos" (p. 109).

E ademais, "eles" são muito hábeis ao apresentar sua história como maiúscula, como única, e transformar em tema somente o que os importa. Nos adverte Freire:

Na medida em que se aprofunda o antagonismo entre os temas que são a expressão da realidade, há uma tendência para a mitificação ${ }^{x}$ da temática e da realidade mesma, o que, de modo geral, instaura um clima de "irracionalismo" e de sectarismo (FREIRE, 1977, p.109).

A atualidade do pensamento de Freire e de sua obra prima coincide desafortunadamente com o sectarismo vivenciado hoje em nosso país. A falaciosa e insistente proposição de que somos uma nação dividida entre os a favor e contra determinado projeto corrobora a máxima maquiavélica de dividir para conquistar. Somo coxinhas ou somos petralhas?

Freire já nos advertia que a sectarização nos leva a acreditar em posições fechadas, “irracionais", rechaçando o diálogo, uma vez que:

[...] a sectarização é sempre castradora, pelo fanatismo de que se nutre [...] a sectarização é mítica, por isto alienante [e] porque mítica e irracional, transforma a realidade numa falsa realidade, que, assim, não pode ser mudada. Parta de quem parta, a sectarização é um obstáculo à emancipação dos homens e mulheres ${ }^{\text {xi }}$ (FREIRE, 1977, p.22).

Além disso, Paulo nos aconselha, enraizado em 1968 - e redundando nos dias de hoje - a sermos "radicais" no sentido de termos fincadas nossas raízes no compromisso com a libertação dos seres humanos, sendo tanto mais radicais quanto mais nos inscrevermos nesta realidade para, conhecendo-a melhor, melhor poder transformá-la. E prenuncia o caminho que o radical deverá seguir, o de não (T)temer ${ }^{\text {xii }}$. O radical:

Não teme enfrentar, não teme ouvir, não teme o desvelamento do mundo. Não teme o encontro com o povo. Não teme o diálogo com ele, de que resulta o crescente saber de ambos. Não se sente dono do tempo, nem dono dos homens e mulheres, nem libertador dos oprimidos. Com eles se compromete, dentro do tempo, para com eles lutar. (FREIRE, 1977, p. 24). 
E viventes em temerosos tempos, acaso de quem tememos as ameaças de destruição da vida humana e de toda a Vida e do Planeta Terra, cada vez mais anunciados e difundidos por cientistas e diferentes instituições?

Vemos, nos mais distintos setores, também outra máxima maquiavélica se consolidando: "Quando fizer o bem, faça-o aos poucos. Quando for praticar o mal, fazê-lo de uma vez só".

Assim, sob o jugo do atual governo, estamos presenciando retrocessos nas mais diferentes áreas, como o Meio Ambiente - com a anulação de Unidades de Conservação e a consequente pressão sobre populações tradicionais e sobre terras e povos indígenas, o aumento dos licenciamentos para as empresas de mineração e hidrelétricas, entre outras; na área da Saúde, tendo o Brasil voltado a ser incluído no Mapa Mundial da Fome, elaborado pela Organização das Nações Unidas (ONU), além da precarização do Sistema Único de Saúde em virtude da ineficiência administrativa e política que atua em benefício de empresas financeiras da saúde e em detrimento dos direitos humanos. $\mathrm{Na}$ interface entre saúde e ambiente testemunhamos a tentativa de aprovação de um projeto de lei envolvendo ao uso e a exposição a agrotóxicos no país - que atende a interesses de setores da economia como a indústria química, do agronegócio e de grandes multinacionais - e coloca em risco toda a população brasileira. Com relação aos retrocessos sociais promovidos nesses últimos dois anos, uma das atitudes mais explícitas é a tentativa de criminalizar movimentos sociais como o Movimento dos Trabalhadores rurais sem Terra (MST) e o Movimento dos Trabalhadores Sem Teto (MTST). Nesse exato momento tramita no Senado Federal uma consulta pública cuja ementa é: “Criminalizar o MST, MTST e outros movimentos ditos sociais que invadem propriedades. Você apoia essa proposição?”.

Essa tentativa de criminalização se sustenta na disseminação do medo e da desinformação sobre a quem realmente devemos temer.

\section{Movimentos sociais e sociedade em movimento}

Temos medo das pessoas e dos coletivos de nossas comunidades tradicionais e de nossos movimentos populares? É de povos de enxada nas mãos, de uma persistente coragem de viver, e de uma ancestral vida solidária e generosamente "sustentável”, bem antes que nós tivéssemos inventado esta palavra ${ }^{x i i i}$.

É deles? Dos povos indígenas que se reproduziram aos milhões nesta terra com outros nomes que depois chamamos de Américas, deixando-a viva e verde enquanto alimentava uma quantidade até hoje não calculada de milhões de pessoas, entre povos e comunidades ancestrais? Devemos desconfiar das intenções e temer as ações deles e delas? 
Ou nosso temor real deverá recair sobre as pessoas, as corporações, as empresas nacionais e multinacionais, os bancos e os seus emissários na política partidária e "legítima"? Sobre aqueles que se arvoram arautos e agentes da "ordem" e do "progresso", e carimbam como "os atrasados", as pessoas, os povos e as comunidades tradicionais? Serão os caminhoneiros ${ }^{\mathrm{xiv}} \mathrm{e}$ suas autênticas reivindicações o que nos preocupa ou as propaladas manipulações dos empresários, as intervenções das forças federais e os decretos de "garantia de lei e da ordem"?

Como sabiamente nos relembra Freire (1977, p.31):

Os opressores, falsamente generosos, têm necessidade, para que a sua "generosidade" continue tendo oportunidade de realizar-se, da permanência da injustiça. A "ordem" social injusta é a fonte geradora, permanente, desta "generosidade" que se nutre da morte, do desalento e da miséria.

Quem são esses falsos generosos, senão os que arrasaram vidas, comunidades e o meio ambiente entre povoados de Mariana, o Rio Doce e o mar do litoral do Espírito Santo? A quem devemos temer? As pessoas que de enxada e com sementes nativas colocam na nossa mesa a comida de todos os dias? Ou os arrancadores dos bens naturais da terra - e da Terra - que eles preferem chamar de "comodities", entre a madeira do eucalipto e os seus desertos verdes, os grãos de soja transgênica, o minério e a madeira, enquanto apregoam a si próprios como sendo a "salvação econômica do País".

Ou devemos nos amedrontar com aquelas pessoas que são os algozes que levam a que imensidões de territórios e de terras de sertão, cerrado e floresta sejam devastados e queimados a cada dia, para que dali saiam em fuga - "a ferro e a fogo" - o ar puro e a água límpida, as plantas ancestrais, os animais nativos e os seres humanos. Para que ali entre o gado, a soja, o eucalipto e as outras monoculturas que alimentam bolsos e bolsas, se esvaiam pratos, mesas e vidas?

Queremos ainda sonhar com um futuro? Para bem além das pequenas máquinas eletrônicas que a cada dia nos dominam as mãos e as mentes, saberemos ainda sonhar com o futuro de um mundo verde, vivo, verdadeiro e virtuosamente - bem mais do que "virtualmente" - humano e humanizado? A quem confiar este futuro? Do que ou de quem esperá-lo? Do Banco Mundial? Do FMI? Da IBM? Da Microsoft? Da Monsanto? Da Friboi? Da Shell? Da Sadia (tão pouco sadia!)?

E retomamos outras perguntas feitas por Freire (1977, p.32): "Quem, melhor que os oprimidos, se encontrará preparado para entender o significado terrível de uma sociedade 
opressora? Quem sentirá, melhor que eles, os efeitos da opressão? Quem, mais que eles, para ir compreendendo a necessidade da libertação?"

E essas pessoas, essas vidas sociais, organizadas em movimentos ou não, é que representam a verdadeira esperança. Segundo Streck (2009, p. 171) a importância dos movimentos sociais expressa na Pedagogia do Oprimido se assenta no fato de eles serem "portadores de uma rebeldia que impulsiona as mudanças na sociedade" e pelo fato de responderem "a desafios específicos de uma classe, de um grupo social, de uma questão social emergente". Ademais, os movimentos sociais, representam espaços de constituição de homens e mulheres como sujeitos, em busca por humanização.

Desde a década de 1960, os movimentos sociais foram escrevendo e inscrevendo suas marcas na história, alçando conquistas do povo e dos povos deste país: indígenas, quilombolas, camponeses, sertanejos, barranqueiros, chapadeiros, pantaneiros, operários, povos da floresta, lavradores do MST e de outros movimentos populares e comunidades populares. Essa também é a nossa cara!

Somos levados a acreditar que os "capitalistas do campo" estão ocupando quase todo o território "aproveitável” do País. Pura ilusão! Mais de 50\% do território brasileiro é ocupado por parques naturais, por terras indígenas, por comunidades quilombolas e as de outros muitos povos e etnias. Ocupados por terras e territórios palmo a palmo conquistados a poder de luta de indígenas e negros, de camponeses sem terra, entre o MST o MTST e outros tantos movimentos de povos e de comunidades de lutas no campo e na cidade.

Querem nos passar a imagem falsa de um povo passivo e inerte, apenas porque desde séculos atrás as nossas lutas populares foram e seguem sendo distorcidas pela mídia vil, a serviço da vileza. E também, depois, desvirtuadas pelos historiadores de plantão. Fomos e seguimos sendo uma das nações com mais tradições de lutas e de movimentos de insurgência aqui na América Latina.

Não será agora a hora de começarmos a desenhar um transgressivo e real "Mapa do Brasil"?

E qual seria o lugar mais adequado para reescrever a História e redesenhar os mapas, para descolonizar mentes e saberes se não a escola?

\section{Educação bancária repaginada: a Escola sem partido!}


Como afirma Frei Betto, "nada mais tendencioso do que o Movimento Escola Sem Partido, que acusa as escolas de abrir espaços a professores esquerdistas que doutrinam ideologicamente os alunos". E complementa:

\begin{abstract}
Uma das falácias da direita é professar a ideologia de que ela não tem ideologia. E a de seus opositores deve ser rechaçada. O que é ideologia? É o óculos que temos atrás dos olhos. Ao encarar a realidade, não vejo meus próprios óculos, mas são eles que me permitem enxergá-la. A ideologia é esse conjunto de ideias incutidas em nossa cabeça e que fundamentam nossos valores e motivam nossas atitudes.
\end{abstract}

Essa proposta de escola sem partido teve sua origem com um procurador do Estado de São Paulo com vistas a estimular a delação de alunos que, supostamente, estariam sofrendo uma “doutrinação marxista, esquerdista” e, portanto, estariam passíveis a processos judiciais. Assim, esse movimento representa novo retrocesso que visa a colocar uma mordaça em professoras e professores radicais, como definido anteriormente:

Para as elites dominadoras, esta rebeldia, que é ameaça a elas, tem o seu remédio em mais dominação - na repressão feita em nome, inclusive, da liberdade e no estabelecimento da ordem e da paz social. Paz social que, no fundo, não é outra senão a paz privada dos dominadores (FREIRE, 1977, p. 75).

A falácia se apresenta já no seu projeto: "escola sem partido: por uma lei contra o abuso da liberdade de ensinar"!

Quem defenderia uma escola unipartidária? Na verdade essa escola apartidária representa uma escola aprisionadora. E aprisionadora das diversidades, das subjetividades, das sexualidades, das pluralidades. Há aqueles que acreditam na possibilidade de uma escola apolítica, e aí reside um grande risco.

Ainda concordando com Freire Betto:

Enfim, é a velha artimanha da direita: já que não convém mudar a realidade, pode-se acobertá-la com palavras. E que não se saiba que desigualdade social decorre da opressão sistêmica; a riqueza, do empobrecimento alheio; a homofobia, do machismo exacerbado; a leitura fundamentalista da Bíblia da miopia que lê o texto fora do contexto.

Perguntamo-nos: poderemos nós, professores e professoras escapar dessas algemas? Certamente sim! Mas isso não vai ocorrer se deixarmos de prestar atenção ao que se passa em nossa unidade epocal, coincidente em muitos aspectos àquela de 50 anos atrás:

A educação como prática da dominação, que vem sendo objeto desta crítica, mantendo a ingenuidade dos educandos, o que pretende, em seu marco ideológico, (nem sempre 
percebido por muitos dos que a realizam) é doutriná-los no sentido de sua acomodação ao mundo da opressão. Quem atua sobre os homens para, doutrinando-os, adaptá-los cada vez mais à realidade que deve permanecer intocada, são os dominadores (FREIRE, 1977, p. 76).

As pessoas que professam a escola sem "doutrinação marxista" se mobilizaram para retirar de Paulo Freire o título de patrono da educação brasileira.

Paulo Freire é reconhecido internacionalmente como um dos educadores mais importantes do Séc. XX, sendo que sua Pedagogia do Oprimido está entre os três livros mais citados nas Ciências Sociais e entre os 100 livros mais pedidos e consultados em universidades de língua inglesa pelo mundo, segundo um levantamento realizado a partir do Google Scholar por Elliot Green da London School of Economics. Por sua indiscutível importância, a Organização das Nações Unidas para a Educação, a Ciência e a Cultura (UNESCO) considerou Patrimônio da Humanidade o acervo de Paulo Freire e o incluiu no programa "Memórias do Mundo".

Sob o olhar desse grupo conservador e reacionário, esse nosso ícone da História mundial, deve ser execrado e, uma vez mais, acusado de subversivo, ateu e comunista.

$\mathrm{Na}$ verdade acusam de "doutrinação" tudo aquilo que ameace seus privilégios, embebidos que estão da crença que suas necessidades (ou privilégios) são as únicas que importam. E sabem que a escola sozinha não promove a mudança, mas sem ela, nada muda! Essa escola sem partido é minúscula e bravata dos dominadores!

Utilizam linguagem advocatícia e reescrevem obviedades que não se discutem, já denunciadas por Freire a 50 anos, de que não é papel da professora ou do professor impor seus "próprios interesses, opiniões, concepções ou preferências ideológicas, religiosas, morais, politicas e partidárias". Quem prescreve, manipula, subjuga é o “educador bancário".

\footnotetext{
Um dos elementos básicos na mediação opressores-oprimidos é a prescrição. Toda prescrição é a imposição da opção de uma consciência à outra. Daí, o sentido alienador das prescrições que transformam a consciência recebedora no que vimos chamando de consciência "hospedeira" da consciência opressora. Por isto, o comportamento dos oprimidos é um comportamento prescrito. Faz-se à base de pautas estranhas a eles - as pautas dos opressores (FREIRE, 1977, p. 34).
}

O que a escola sem partido afirma é que professoras e professores se "aproveitariam da 'audiência cativa dos alunos' para promover sua ideologia".

Estamos longe de considerar que crianças e adolescentes são 'audiência cativa'! Nossas alunas e alunos, pelo contrário, são sujeitos de sua própria história e, por isso, livres. Como sempre afirmou Freire, o conteúdo programático da educação jamais pode ser uma "doação" ou 
“imposição" por parte de professoras e professores. Quem faz isso, repetimos, são os dominadores.

O discurso desse grupo que pretende deslegitimar o pensamento freireano, ademais, não esconde a ideologia machista e sexista de onde parte, subsumindo a presença das mais de $80 \%$ de mulheres da educação básica, tratando-as como "professores". Suas ideias, concepções, esperanças, dúvidas, valores, desafios, desaparecem na declinação do masculino como genérico. E isso se traduz como colonialidade e patriarcado, o que professam inconfessadamente.

Sob a égide da "normalidade", do "natural", da "ordem" e do "progresso", a escola com mordaça segue tentando fazer as professoras desaparecerem sob as costelas dos homens e ainda vaticina que nem elas ou eles deverão "favorecer ou prejudicar os alunos em razão de suas convicções políticas, ideológicas, morais e religiosas, ou da falta delas", tampouco fazer propaganda político-partidária na sala de aula.

Esse manto de moralidade, na realidade, representa uma tentativa espúria de consolidar “cárceres sem partido". Para Gadotti $(2016, \mathrm{~s} / \mathrm{p})^{\mathrm{xv}}$ :

A expressão "Escola sem partido" e "Escola de partido único" são sinônimos. Trata-se de uma escola sem pluralidade, sem liberdade, sem diversidade, sem inclusão, sem democracia, uma escola que segrega, que discrimina, que reprime. Além disso, o movimento da Escola Sem Partido é um movimento a favor da privatização da educação. Primeiro desqualifica a escola pública para, depois, propor "recuperar" essa escola por meio da gestão privada ou dos critérios privados de institutos e fundações empresariais. A Escola Sem Partido é apenas mais uma tentativa de destruir a Escola Democrática, a Escola Cidadã, uma conquista da Constituição de 1988 e da Lei de Diretrizes e Bases da Educação Nacional de 1996.

O que esperar de grupos que representam as elites mais cruéis e cruentas de nosso país, ao propor, supostamente, com esse projeto de escola sem partido uma "educação escolar mais coerente", se não a coerência com seus próprios interesses?

O opressor só se solidariza com os oprimidos quando o seu gesto deixa de ser um gesto piegas e sentimental, de caráter individual, e passa a ser um ato de amor àqueles. Quando, para ele, os oprimidos deixam de ser uma designação abstrata e passam a ser os homens e mulheres concretos, injustiçados e roubados. Roubados na sua palavra, por isto no seu trabalho comprado, que significa a sua pessoa vendida. Só na plenitude deste ato de amar, na sua existenciação, na sua práxis, se constitui a solidariedade verdadeira. Dizer que os homens e mulheres são pessoas e, como pessoas, são livres, e nada concretamente fazer para que esta afirmação se objetive, é uma farsa. (FREIRE, 1977, p. 38).

\section{Tradição, família e propriedade ${ }^{\mathrm{xvi}}$ - de quem, cara pálida?}


Não somos a falsa "cara" com que se desenha este País e seu povo. Temos um outro "rosto". Temos uma "cara" que é nossa, e precisamos mostrar a nós mesmos e aos outros como é este rosto, como é esta "cara".

Enquanto a TV Globo exagera imagens e notícias que fazem as favelas do Rio de Janeiro parecerem antros povoados por bandidos e traficantes, sabemos que várias vezes agências de pesquisa e de notícias chegam do exterior ao Rio de Janeiro para descobrirem nas comunidades pobres da cidade, onde nasceu um dos autores, alguns dos locais do Planeta mais povoados por mulheres e homens pobres e trabalhadores.

Uma gente pronta a ensinar ao mundo lições diárias de vidas entregues ao trabalho, de "portas abertas", de solidariedade, de ativa gestão da vida comunitária e de resistência à opressão. Boa parte do que veio a ser a sociologia jurídica de Boaventura de Souza Santos nasceu de sua pesquisa da Comunidade do Jacarezinho, no Rio de Janeiro ${ }^{\text {xvii }}$.

Somos também as tantas pessoas que colocam os seus saberes adquiridos entre anos e anos de estudo e pesquisa nas universidades, a serviço das frentes populares de luta e de insurgência. E precisamos de mais e mais gente capaz de deixar pelo caminho os apelos e as ofertas que os senhores do poder e do mercado fazem ou impõem a quem pode se dedicar a pensar, a pesquisar e a escrever.

E somos pessoas vocacionadas a colocar o que aprendemos e ensinamos a serviço daqueles a quem deve caber a linha de frente na construção de "um outro mundo possível", como vimos gritando nas ruas, nas edições de fóruns e levantes e nos mais distintos espaços sociais, em nossas vidas sociais.

Não somos os falsos juízes e nem os políticos viciados em espoliarem o povo e o País, e a reproduzirem ao longo dos anos as piores lições de cidadania. Não somos os senhores do poder e nem somos a fração mínima de empresários e de milionários que concentram em nome do capital mais de $80 \%$ das riquezas que o trabalho do povo produz. Não somos os senhores do agronegócio, e nem quem bate-panela e sai às ruas trajados de verde-e-amarelo para falar em favor dos que andam e tramam entre os palácios e os congressos... vestidos de lama.

Não possuímos a "tradição", a "família" e tampouco usuramos ou usurpamos a "propriedade" dentro dos moldes dos conservadores de plantão, entre eles os representantes da TFP e todas as pessoas que professam valores radicados no capitalismo, no colonalismo, e no hetero-patriarcado, como aponta Santos $(2018)^{\text {xviii }}$.

Muito dessa "tradição" é inventada, usando os termos de Eric Hobsbawn (1997), cuja base está relacionada a um passado histórico específico e se forja em uma continuidade bastante 
artificial, tomando para si ou seu passado uma referência quase que obrigatória, se arvorando verdade única e invariável.

Não seria, portanto, a tradição vigente nas sociedades tradicionais (a que Hobsbawn intitula "costume"), cuja função é de motor e volante, de fundação e horizonte.

A tradição que propalam os opressores tem como alicerce seu apoio incondicional a uma família monogâmica (heterossexual, por suposto) e indissolúvel; ao valor intrínseco das elites para o ordenamento social; à moralidade televisiva; ao porte de armas e direito de defesa; à manutenção de uma escala hierárquica em todos os âmbitos da sociedade e da Igreja; ao antimodernismo; ao anti-comunismo, (ZANOTTO, 2010) entre outros elementos doutrinários e excludentes.

Frente a isso Freire nos auxilia a "reconhecer a desumanização, não apenas como viabilidade ontológica, mas como realidade histórica", e nos instiga à busca por outra viabilidade: a humanização. E para ele, somente a humanização é vocação de homens e mulheres a qual, mesmo negada, é afirmada nessa própria negação: "Vocação negada na injustiça, na exploração, na opressão, na violência dos opressores. Mas afirmada no anseio de liberdade, de justiça, de luta dos oprimidos, pela recuperação de sua humanidade roubada”. (FREIRE, 1977, p. 30).

A família defendida e imposta pelos dominadores, por sua parte, se baseia em pressupostos pautados no patriarcado, no qual os homens representam os provedores econômicos, os líderes políticos e religiosos e os chefes de família. Às mulheres cabem funções como esposas, donas-de-casa e educadoras dos filhos - não são "seres para si", como sugere Freire. Ao contrário, servem aos outros - pais, maridos e/ou filhos - e ademais, a mulher deve ser "recatada, bela e do lar", como largamente veiculado na fala de um certo político a quem sugerimos temer.

Essa concepção reforça e naturaliza a violência de gênero na sociedade brasileira e ainda atribui às mulheres, meninas, travestis e transexuais a responsabilidade pela violência sofrida. E novamente convidamos Freire ao diálogo: "Inauguram a violência os que oprimem, os que exploram, os que não se reconhecem nos outros; não os oprimidos, os explorados, os que não são reconhecidos pelos que os oprimem como outro." (P. 45)

Por fim, a propriedade que os dominadores e terratenientes defendem é a "propriedade familiar privada", da mesma família de elite, heterossexual, branca, monogâmica, indissolúvel, ou seja, da família "deles". A propriedade "é considerada, acima de tudo, como condição de humanidade e superioridade do homem em relação ao mundo natural", que tomam como sua e 
para cuja ganância não há limites, uma vez que possuem “[...] o direito legítimo de apropriação ilimitada de terras" (ZANOTTO, 2010, p. 123, grifo nosso).

\section{Do luto à luta ${ }^{\mathrm{xix}}$ - Anúncios de outro mundo possível}

Em Ação Cultural para a libertação, discutimos mais amplamente este sentido profético e esperançoso da educação (ou ação cultural) problematizadora. Profetismo e esperança que resultam do caráter utópico de tal forma de ação, tomando-se a utopia como a unidade, inquebrantável entre a denúncia e o anúncio. Denúncia de uma realidade desumanizante e anúncio de uma realidade em que os homens possam ser mais. Anúncio e denúncia não são, porém, palavras vazias, mas compromisso histórico (FREIRE, 1977, p. 84).

Saibamos ser desde este presente que recomeça sempre hoje, a presença crítica e criativamente ativa; a aguerrida ousadia; a luta de agora e a esperança de sempre. Saibamos, ao lado de nossa capacidade de denúncia e de oposição não apenas a um governo transitório, mas a todo o perverso sistema que o gerou e alimenta, nos unir mais ainda do que antes. E estarmos juntas, juntos, e não apenas com nossas palavras e nossas bandeiras de resistência ativa e luta. Saibamos aprender com as comunidades tradicionais, com os movimentos sociais, com as sociedades em movimento e as mais diferentes vidas sociais a viver no presente e a projetar para o futuro o que já é uma realidade entre elas.

Saibamos responder ao agronegócio devastador de terras e de vidas com a agricultura familiar. Saibamos responder à falsa tecnologia dos venenos e dos transgênicos com a agroecologia e as suas variantes. Saibamos responder à solidão dos latifúndios com as diferentes modalidades de uma agricultura coletivizada e solidária, desde comunidades patrimoniais que pelos séculos reproduzem com o seu trabalho as condições de existência de nossas vidas.

Saibamos responder ao cercamento crescente (haja arame farpado!) de territórios antes livres, de terras dos pobres e de caminhos de águas e de aguadas, com as nossas comunidades tradicionais e os nossos assentamentos de camponeses livres, onde sequer há porteiras e se entra e sai em/de uma terra "nossa" e não "minha".

Saibamos opor às "alfavilles", cercadas de muros e de homens armados, com as nossas "ecovilas" que se recriam e se multiplicam entre pequenas e fecundas teias e redes de vida, por toda a parte. Saibamos responder à economia de mercado - aquela que transforma alguns poucos em "investidores de sucesso", e todos os outros em mercadorias - com as diversas experiências vindas do "chão da vida", como a economia solidária, a economia do dom e as outras economias que buscam recriar alternativas de trocas entre pessoas através das coisas, ao invés de reiterar trocas entre coisas através das pessoas. 
Saibamos responder a todo um perverso processo capitalista de privatização de tudo o que possa ser transformado de "dom entre as pessoas" em "bens de algumas pessoas" - como a educação, a saúde, a previdência, a habitação, a alimentação e tanto mais - opondo a uma crescente colonização de vidas e subordinação da própria vida aos ganhos do capital, uma persistente luta em favor de uma socialização humana e humanizadora. Um socialismo com liberdade entre pessoas socialmente tornadas iguais, e em tudo o mais abertas ao direito de todas as diferenças que nos irmanam e libertam.

Saibamos opor - sem fundamentalismo algum nisto - a uma crescente "geleia geral" da cultura, que vai do "ensino empacotado" nas escolas, das "escolas com mordaças" e os “programas mínimos" de educação, à transformação de culturas em "negócios culturais", com um forte apelo a uma redescoberta e a uma revalorização - de dentro para fora e de baixo para cima - de todo o valor de saber e ciência do "senso comum" de nossos diferentes movimentos, povos, tradições e patrimônios culturais.

Somos uma outra gente e temos na verdade um outro rosto. Como, em outros escritos, nos sugere Freire (1997, p.08, grifo nosso):

É preciso ousar, no pleno sentido desta palavra, para falar em amor, sem temer ser chamado de piegas, de meloso, de a-científico, senão de anticientífico. É preciso ousar para dizer cientificamente que estudamos, aprendemos, ensinamos, conhecemos com o nosso corpo inteiro. Com sentimentos, com as emoções, com os desejos, com os medos, com as dúvidas, com a paixão e também com a razão crítica. Jamais com esta apenas. É preciso ousar para jamais dicotomizar o cognitivo do emocional.

Quando ouvirmos de novo: "Brasil, mostra a sua cara", deixemos que os que se escondem atrás de suas máscaras mostrem a "cara" que eles têm. E saibamos olhar para nós mesmos, a começar por aqueles que esperam de nós bem mais do que um simples "apoio".

E, com eles, mostrar a nós mesmos e aos outros a cara verdadeira de nossos rostos.

Até o momento em que de tanto assim ser, venhamos a tornar reais as palavras de Paulo Freire, quando há mais de 50 anos ele nos lembrava que uma educação que deseje ser, mais do que apenas "popular", uma prática libertadora e transformadora de pessoas, destinos, vidas, comunidades e sociedades inteiras, precisa reinventar-se. Precisa saber que ninguém educa ninguém. Mas que também ninguém se educa a si-mesmo. Nós, mútua e dialogicamente, nos ensinamos-e-aprendemos uns-às-outras, umas-com-os-outros, a partir de nossas diferenças e em nome de tornar um dia inexistente tudo aquilo que ainda nos faz sermos desiguais.

\section{Referências}

Revista Interinstitucional Artes de Educar. Rio de Janeiro, V. 4 N. 2 - pag 294-313 (mai - ago 2018): "Dossiê 50 anos da Pedagogia do Oprimido: movimentos de opressões e emancipações contemporâneas na América Latina e África" DOI:10.12957/riae.2018.38029 
ANDREOLA, Baldoíno. Freire e Fiori no exílio: um projeto pedagógico-político no Chile, Canoas/RS: Editora Ritter, 2001.

ANDREOLA, Baldoíno. Andarilho da Esperança: Paulo Freire no CMI (Conselho Mundial de Igrejas). São Paulo: Editora ASTE, 2005.

BRASIL. Estudo exploratório sobre o professor brasileiro com base nos resultados do Censo Escolar da Educação Básica 2007/Instituto Nacional de Estudos e Pesquisas Educacionais Anísio Teixeira. - Brasília: Inep, 2009.

BRANDÃO, Carlos Rodrigues. Paulo Freire: a educação, a cultura e a universidade - memória de uma história cinquenta anos atrás. Revista EJA em Debate, Edição Especial, ano 3, n 4, 2014. DUSSEL, Enrique. Cultura imperial, cultura ilustrada y liberación de la cultura popular. (apêndice). In: DUSSEL, Henrique. Para uma ética da Libertação Latino-Americana: III Erótica e Pedagógica. Piracicaba/São Paulo: Co-edição Edições Loyola/Editora UNIMEP, 1974.

FÁVERO, Osmar. Cultura popular e educação popular - memoria dos anos sessenta. Rio de Janeiro: GRAAL, 1985.

FREIRE, Paulo. Pedagogia do Oprimido. 4. ed. Rio de Janeiro: Paz e Terra, 1977. Pedagogia da esperança: um reencontro com a pedagogia do oprimido. Rio de Janeiro: Paz e Terra, 1992. Professora sim, tia não. Cartas a quem ousa ensinar. São Paulo: Olho D’água, 1997.

GALEANO, Eduardo. A descoberta da América (que ainda não houve). Trad. Eric Nepomuceno. Porto Alegre: Editora da Universidade/UFRGS, 1976.

HOBSBAWN, Eric; RANGER, Terence. A Invenção das Tradições. Tradução de Celina Cavalcante - Rio de Janeiro: Paz e Terra, 1997.

QUIJANO, Anibal. Colonialidade do poder, eurocentrismo e América Latina. In: LANDER, Edgardo (org.) A colonialidade do saber: eurocentrismo e ciências sociais. Perspectivas latinoamericanas. Colección Sur Sur, CLACSO, Buenos Aires, Argentina, 2005, p. 107-130.

SANTOS, Milton. O espaço do cidadão. 7ª . Ed. V. 8. São Paulo: Edusp, 2007.

STRECK, Danilo. Uma pedagogia do movimento: Os movimentos sociais na obra de Paulo Freire. Revista Educação Pública. Cuiabá, v. 18, n. 36, p. 165-177, jan./abr. 2009.

ZANOTTO, Gizele. Normatizações, controle e disciplina: a TFP enquanto instituição total (1960-1995). História, Franca , v. 29, n. 2, p. 206-220, Dec. 2010 . Disponível em: http://www.scielo.br/scielo.php?script=sci_arttext\&pid=S0101- 
em 27 Maio 2018. http://dx.doi.org/10.1590/S0101-90742010000200011.

Tradição, família e propriedade (TFP): as idiossincrasias de um movimento católico (1960-1995). Tese (Doutorado em História). Centro de Filosofia e Ciências Humanas. Universidade Federal de Santa Catarina, 2007.

i Centro Universitário Salesiano de São Paulo Unidade Americana - Campus Maria Auxiliadora

ii Licenciado em psicologia e Psicólogo pela Pontifícia Universidade Católica do Rio de Janeiro (1965); mestre em antropologia pela Universidade de Brasília (1974). doutor em ciências sociais pela Universidade de São Paulo (1980); livre docente em antropologia do simbolismo pela Universidade Estadual de Campinas. Realizou pósdoutorado na Universidade de Perugia e na Universidade de Santiago de Compostela. É "fellow" do St. Edmund's College da Universidade de Cambridge. Atualmente é professor colaborador do Programa de Pós-Graduação em Antropologia da Universidade Estadual de Campinas (UNICAMP), professor colaborador do POSGEO da Universidade Federal de Uberlândia (UFU) e professor visitante da Universidade Estadual de Goiás. Possui experiência na área de antropologia, com ênfase em antropologia camponesa, antropologia da religião, cultura popular, etnia e educação, com foco na educação popular É Comendador do Mérito Científico pelo Ministério de Ciência e Tecnologia, doutor honoris causa pela Universidade Federal de Goiás, doutor honoris causa pela Universidad Nacional de Lujan (Argentina), professor emérito da Universidade Federal de Uberlândia, e professor emérito da Universidade Estadual de Campinas. Escreveu artigos e livros nas áreas de antropologia, educação e literatura.

iii O livro é da Editora GRAAL, do Rio de Janeiro, e é do ano de 1985. Carlos Brandão escreveu um artigo a respeito da equipe pioneira de Paulo Freire e a proposta de seu "sistema". Ver Paulo Freire: a educação, a cultura e a universidade - memória de uma história cinquenta anos atrás. Revista EJA em Debate, Edição Especial, ano 3, nº 4, 2014.

iv Um curioso e lastimável pequeno detalhe merece ser lembrado. Como o processo de alfabetização requeria a projeção das "fichas de cultura" do Método Paulo Freire e como na maior parte dos casos as reuniões seriam em cenários rurais sem energia elétrica, projetores de slides a querosene deveriam ser comprados em grande quantidade. Apenas nos EUA e na Polônia foram encontrados. Sendo muito caros os norte-americanos e bem mais baratos e eficientes os poloneses, foram estes últimos os escolhidos. Dias após o golpe militar de $1^{\circ}$ de abril de 1964 , a apresentadora Sandra Cavalcanti exibia um dos projetores em um noticiário de televisão declarando que uma das provas de que o "método do professor Paulo Freire" era comunista residia em que "até os projetores vêm de um país comunista".

${ }^{v}$ Pouco conhecidos, mesmo entre educadores, existem dois livros de Baldoino Andreola, da UFRGS, sobre os anos de exílio de Paulo Freire. Um deles é Freire e Fiori no exílio: um projeto pedagógico-político no Chile, publicado pela Editora Ritter, de Canoas, Rio Grande do Sul, em 2001. O outro é Andarilho da Esperança: Paulo Freire no CMI (Conselho Mundial de Igrejas), publicado pela Editora ASTE, de São Paulo, em 2005.

${ }^{\text {vi }}$ Trata-se de um texto de 1976, chamado "Em defesa da Palavra", que é o primeiro do pequeno livro "A descoberta da América (que ainda não houve)".

vii "Uma unidade epocal se caracteriza pelo conjunto de ideias, de concepções, esperanças, dúvidas, valores, desafios, em interação dialética com seus contrários, buscando plenitude. A representação concreta de muitas destas ideias, destes valores, destas concepções e esperanças, como também os obstáculos ao ser mais dos homens e mulheres, constituem os temas da época". (FREIRE, 1977, p.109).

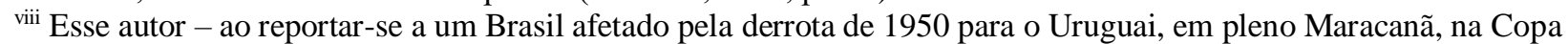
do Mundo de futebol - vem a afirmar que, em todos os setores [mas principalmente no futebol, naquele momento], o povo brasileiro se coloca, voluntariamente, em posição de inferioridade em face do resto do mundo. Nelson Rodrigues não assistiu ao "7 X 1", 54 anos depois. Tampouco assistiu às mais recentes mazelas enfrentadas por nossa sociedade.

ix Não é intenção desse texto aprofundar discussões sobre essa "unidade epocal". Entretanto, importante ressaltar que o documentário traz graves denúncias, a partir de documentos secretos e gravações originais, sobre a participação estadunidense no Golpe Militar que compensam ser (re)visitadas e problematizadas, inclusive refletindo sobre os porquês da atual crise brasileira e seus desdobramentos.

${ }^{\mathrm{x}}$ As recentes e estapafúrdias estatísticas de intenção de voto escancaram a atualidade desse pensamento: fortalecemse as ideias de um candidato que se auto professa misógino, misantropo, homofóbico, racista, sexista... E ainda 
granjeia o status de "mito". E precisamos ter cada vez em maior número vozes a alertar para o perigo que isso representa!

xi Em Pedagogia da Esperança Freire reforçou a necessária revisão de uma linguagem machista, tomando o "masculino" como "genérico". Nesse texto re-escrevemos e acrescentamos a mulher nas transcrições literais de seus escritos, buscando uma coerência com a atualidade de seu pensamento. Para ele: "Não é puro idealismo, acrescentese, não esperar que o mundo mude radicalmente para que se vá mudando a linguagem. Mudar a linguagem faz parte do processo de mudar o mundo. A relação entre linguagem-pensamento-mundo é uma relação dialética, processual, contraditória. É claro que a superação do discurso machista, como a superação de qualquer discurso autoritário, exige ou nos coloca a necessidade de, concomitantemente com o novo discurso, democrático, antidiscriminatório, nos engajarmos em práticas também democráticas. O que não é possível é simplesmente fazer o discurso democrático, antidiscriminatório e ter uma prática colonial”. (FREIRE, 2002, p. 68)

xii Se usamos esse recurso de associar o nome próprio Temer ao verbo temer não é por considerarmos que o famoso político, nos dias presentes, com esse sobrenome, seja o único a temer... Ledo engano. A quem tememos e devemos temer são aqueles que compactuam das mesmas ideias, concepções e valores. Os retrocessos do atual governo se escancaram no slogan que o Palácio do Planalto escolheu para sintetizar os dois anos de Michel Temer à frente da Presidência da República: “O Brasil voltou, 20 anos em 2". Disponível em: https://www1.folha.uol.com.br/poder/2018/05/o-brasil-voltou-20-anos-em-2-diz-convite-de-comemoracao-dogoverno-temer.shtml

xiii Brandão narra aqui o que disse um líder camponês do Norte de Minas em uma das mesas redondas em que esteve presente. Contou ele a estória de um bando de gente jovem que ao redor de uma conversa, falava sobre os seus desejos e projetos de futuro. E dizia um: "eu quero ser médico". E o outro: "eu quero ser político". E um terceiro: "eu quero ser advogado". E mais outro: "quero estudar pra ser um diplomata". E assim por diante. E foi quando chegou a vez de um último, um jovem vindo da roça. E depois de ouvir os outros ele disse: "e eu só quero ter nas mãos uma enxada bem afiada pra poder plantar, colher e dar o que comer a vocês todos"!

xiv "Nossa cara" é a de cerca de 1200 bloqueios em estradas brasileiras no final de maio/2018 no oitavo dia de uma greve mobilizada por caminhoneiros e caminhoneiras. E por trás dessas pessoas guerreiras está um profundo desejo por Ser Mais. Por serem consideradas cidadãs de direitos. Por poderem viver, elas e suas famílias, com dignidade, com respeito, com paz. As forças armadas foram convocadas para reestabelecer a "ordem". Além disso, foram assinados dois Decretos: de Garantia da Lei e da Ordem (GLO) e Reaquisição de bens.

${ }^{x v}$ Esse trecho está disponível no site: https://resistenciaelutablog.wordpress.com/2016/09/02/a-escola-cidada-frentea-escola-sem-partido/

xvi Segundo Zanotto (2010, p. 206): "Em 26 de julho de 1960, na cidade de São Paulo/SP, um grupo de católicos identificados com a doutrina tradicional desta religião institucionaliza [católica] a associação civil denominada Sociedade Brasileira de Defesa da Tradição, Família e Propriedade (SBDTFP ou, simplesmente, TFP). Este grupo, encabeçado pelo leigo Plínio Corrêa de Oliveira (1908-1995), estabelece então um órgão de atuação que dê suporte às suas campanhas e atividades destinadas, sobretudo, à defesa do trinômio: tradição (católica conservadora), família (patriarcal, monogâmica e indissolúvel) e propriedade (privada)".

xvii Depois de vários livros anteriores, Boaventura de Sousa Santos resolveu editar o que foi a sua tese de doutoramento. Ver: SANTOS, B.S.S. O direito dos oprimidos. São Paulo: Cortez, 2015.

xviii Esse é um pensamento recorrente na obra do sociólogo português. Recentemente publicou um interessante texto em homenagem a Marielle Franco e que ilustra bastante sucintamente seu pensamento. Disponível em https://www.publico.pt/2018/03/30/sociedade/opiniao/o-colonialismo-insidioso-1808254

${ }^{\text {xix }}$ Esse item emprestou o título de um interessante documentário sobre familiares e pessoas com Síndrome de Down dirigido por Evaldo Mocarzel. O filme foi financiado pelo Programa Avançado de Assistência e Tratamento de Pessoas Especiais da Petrobrás, no ano de 2005. Há também um livro publicado em 2001 pela editora Casa de Minas, com o mesmo nome, de autoria de Gláucia Rezende Tavares e colaboradores. Nesse item, entretanto, o luto e a luta tratados se reportam especificamente às denúncias e anúncios abordados por Paulo Freire na Pedagogia do Oprimido. 